\title{
The Influence of Person-Job Fit, Work-Life Balance, and Work Conditions on Organizational Commitment: Investigating the Mediation of Job Satisfaction in the Private Sector of the Emerging Market
}

\author{
Tania Hasan ${ }^{1, *}$, Mehwish Jawaad ${ }^{1}$ and Irfan Butt ${ }^{2}$ \\ 1 Department of Business Administration, Lahore School of Economics, Lahore 54000, Pakistan; \\ mehwishj@lahoreschool.edu.pk \\ 2 Marketing Management Department, Ted Rogers School of Management, Ryerson University, \\ Toronto, ON M5B 2K3, Canada; irfan.butt@ryerson.ca \\ * Correspondence: tania@lahoreschool.edu.pk
}

check for

updates

Citation: Hasan, T.; Jawaad, M.; Butt, I. The Influence of Person-Job Fit, Work-Life Balance, and Work Conditions on Organizational Commitment: Investigating the Mediation of Job Satisfaction in the Private Sector of the Emerging Market. Sustainability 2021, 13, 6622. https://doi.org/10.3390/su13126622

Academic Editor: Guy Hochman

Received: 22 April 2021

Accepted: 6 June 2021

Published: 10 June 2021

Publisher's Note: MDPI stays neutral with regard to jurisdictional claims in published maps and institutional affiliations.

Copyright: (c) 2021 by the authors. Licensee MDPI, Basel, Switzerland. This article is an open access article distributed under the terms and conditions of the Creative Commons Attribution (CC BY) license (https:// creativecommons.org/licenses/by/ $4.0 /)$.

\begin{abstract}
This study aims to provide critical managerial implications for human resource (HR) practitioners at private-sector organizations from an emerging economy perspective. The study helps to optimize organizational commitment in the assessment of work-life balance, person-job fit, work condition, and the mediation of job satisfaction. It also investigates the influence of certain demographic variables on organizational commitment. The population comprises employees working in private sector organizations across Pakistan. A total of 1100 survey questionnaires were sent to potential respondents; 843 responded, giving a response rate of $77 \%$. SmartPLS 3 software and SPSS were used to perform structural equation modeling. The study revealed that work-life balance, person-job fit, and job satisfaction have a positive influence on organizational commitment. Job satisfaction intervenes complementarily with the relationship of work-life balance and person-job fit with organizational commitment, while full mediation of job satisfaction was found for work conditions. Age, female gender, experience with current employee, and total industry experience were positively related to organizational commitment. HR managers at private-sector organizations must strive to provide work-life balance, person-job fit, and better work conditions so that employees are optimally satisfied on the job and exercise strong affective organizational commitment.
\end{abstract}

Keywords: work-life balance; person-job fit; work conditions; job satisfaction; affective organizational commitment

\section{Introduction}

Academicians have investigated the relationship between human resource management systems and organizational performance for over two decades now [1]. Talent mobility in the 21st century has reached unprecedented levels, as the workforce seeks constant gratification of their individual demands [2]. Therefore, retaining an employee that is not only skilled, but also maintains a work-life balance along with a perceived fit between self and organization, has become increasingly essential [2]. The current century is an era marked by greater levels of employee mobility, as they constantly seek higher gratification of their own objectives, hence making it imperative for the organization to strive harder to retain them not only as satisfied employees, but also as having a greater affective organizational commitment [2]. For the same reason, organizations continually strive to foster an encouraging climate to help employees maintain a work-life balance by providing positive work conditions and to endow adequate training to attain person-job fit [3].

The current study responds to the research by Mahmood et al. in 2019, which called for further investigating the area in the context of Eastern cultures and developing countries [1]. Therefore, in this study, the relationship of work-life balance, person-job fit, 
and work conditions is investigated in reference to affective organizational commitment. Furthermore, the mediating role of job satisfaction is also studied. These constructs are an essential part of human resource management systems, which are carefully designed to enhance employee participation and performance [4,5]. Higher levels of employee morale and performance ensured by human resource management will result in enhanced job satisfaction and greater affective organizational commitment, thereby achieving the ultimate purpose of a sustainable competitive advantage for the company [6,7]. This study attempts to build on previous research and provide a larger view of the phenomenon within the private sector from the emerging economy perspective.

Pakistan is among the emerging economies, and with the rising standards of development, the environment at the workplaces has increased in competition. Firms now require optimally qualified and highly skilled employees, as this determines the quality of organizational output and productivity [8]. On the other hand, these employees look for workplaces that offer them good work conditions, attractive remuneration, work-life balance, and person-job fit [9]. Retaining skilled employees has mostly been a dilemma for HR practitioners [10]. Furthermore, in the private sector, as appraisals are performance-based, dissimilarities subsist regarding salary structures, fringe benefits, work conditions, and recognition, which leads to changes in job satisfaction and affective organizational commitment [11]. These disparities are mainly due to the differences in the industry, the HR policies of the company, and the qualifications/skills of the employees [12]. The market setup of Pakistan is still unstructured, and therefore, private companies, both local and multinational, have to face innumerous impediments with issues such as job satisfaction and affective organizational commitment, resulting in rising frustration amongst employees [1].

The current study provides a fresh perspective in the field of HR and organizational behavior. Previous research conducted by Fabi et al. (2015) in Canada and another work conducted in Spain by Luna-Arocas and Camps (2008) tested the relationship between job satisfaction and affective organizational commitment, with a high power work system (HPWS) as antecedents [7,13]. The current study extends their work and investigates the influence of person-job fit, work conditions, and work-life balance as the antecedents for job satisfaction and affective organizational commitment.

There is a dominance of the U.S. paradigm in management research that generally endorses context-free knowledge [14]. They encourage Western-trained researchers to conduct HRM research in non-Western countries to address this imbalance. Brewster (2007) contends that a set of HR practices will work differently in dissimilar social settings because of contingency-oriented approaches [15]. Lane and Wood (2009) state that work practices differ at national and sectoral levels [16]. It has been argued that some Western high-performance work practices might not be affective in an Asian country context [17]. It is, therefore, important to understand the HRM systems within a certain management and national culture context [18].

According to Warsi et al. (2009), HR practices and strategies are still inadequately evident and insufficiently theorized in South Asia [12]. This study provided a basis to extend the discussion in the same region and presented an emerging economy perspective. Some research in the wider context of Asia has been found, which provides evidence that human resource practices cause variation in the way employees perceive, which further influences their behavior and attitudes [19-21]. Studies conducted in the neighboring country of India confirmed that striving for greater employee commitment leads to beneficial results in terms of organizational productivity [22,23].

Although significant research about the human resource practices and affective organizational commitment has been done in the past, according to Mahmood et al. (2019), there is a dearth of studies in South Asia in general, and very few studies have been conducted on Pakistan and none specifically on the entire private sector, to the best of our knowledge [1]. Some investigations carried out in the region have focused on specific industries only, which include a study by Azeem and Akhtar (2014), who investigated 
the Indian health care sector [24]. Furthermore, a study was conducted by Farzaneh et al. (2014) on Gas Transfer Company in Iran, while Akter et al. (2019) investigated university teachers in Bangladesh [25,26]. In Pakistan, Jawaad et al. (2019) explored the telecom sector, and Mahmood et al. (2019) presented a comparison between private and public sector banking employees $[1,27]$.

Among academicians, little has been identified about the implications of the hypothesized relationships of work-life balance, person-job fit, and working condition with affective organizational commitment via the intervening character of job satisfaction. Lok and Crawford (2004) investigated the influence of education, age, and experience on affective organizational commitment in Australian and Chinese samples and suggested that these relationships should be further probed in other societies with varied managerial practices, philosophies, and organizational cultures [28]. Moreover, Straatmann et al. (2020), in a fairly recent study, called for investigating affective organizational commitment for employees relevant to both the duration of employment in the organization and total experience in the industry [29].

The conceptual framework of the current study is comprised of constructs that have never been investigated holistically in a single study for private or public sector employees in developing or developed countries, to the best of our knowledge. Therefore, the current study adds to the existing literature in the area, as it provides a unique perspective of optimizing the affective organizational commitment in the assessment of work-life balance, person-job fit, working condition, and mediation of job satisfaction in the inadequately investigated and evolving context of various private sector industries of Pakistan.

In summary, this study makes a contribution to the existing literature in five aspects. First, it introduces the constructs of person-job fit and work-life balance, along with work conditions as antecedents to job satisfaction, as there are hardly any studies that have examined these antecedents in a collective manner. Second, it provides empirical evidence for the conceptually proposed, but hardly tested relationship between person-job fit and affective organization commitment using social exchange theory. Third, it strengthens the conjectural underpinnings of the proposed relationships using multiple theories, social exchange theory (SET) and conservation of resources (COR) theory. Fourth, it uses a large sample size across multiple industries to improve the generalizability of the findings. Fifth, it uses an emerging market context to test the validity of the theoretical concepts mainly originating from developed countries with a different contextual environment.

\subsection{Literature Review and Hypothesis Development}

\subsubsection{Underpinning Theory}

The current research study is grounded in social exchange theory and conservation of resources (COR) theory $[30,31]$. It explains how and why employers strive to aid employees in the maintenance of work-life balance, provide conducive work conditions, and facilitate person-job fit, which will contribute towards higher job satisfaction and eventually higher affective organizational commitment. According to COR theory, an individual strives to acquire and retain valuable resources such as self-esteem and time, while the loss of these resources results in great psychological distress. When the demands at the workplace increase, it results in greater spending of the resource such as time and energy, which are limited, and hence less of them are available to be spent with the family [32,33].

Social exchange theory proposes that employees are optimally satisfied and offer a higher commitment to the organization if the latter provides them with support and care for their family life [34-36].

\subsubsection{Work-Life Balance and Affective Organizational Commitment}

In recent years, significant attention has been given to the construct of work-life balance (WLB); however, it is evident that minimal focus was given to exploring the concept with regard to private sector employees [37-39]. Compared with the public sector, the private sector faces an increased demand for new products, intense competition, 
need for technological advancements, extended working hours, and hectic schedules, particularly in a South Asian context, which makes it imperative to investigate work-life balance among private-sector employees [40]. According to Greenhaus et al. (2003), worklife balance refers to a balanced fulfillment between both personal responsibilities and occupational roles [41]. It basically refers to having steadiness and stability amongst the professional responsibilities and personal engagements that are critical to individuals, like community roles, the activity of leisure, and family responsibilities. For most employees working in various industries from the private sector, striking this balance has largely been a challenge [42]. When an individual stays occupied with work-related roles, there will be a higher probability that work-life balance will be disturbed, resulting in increased job dissatisfaction and reduced commitment, leading to psychological stress [43]. Employees normally strive for adaptable arrangements at work so that they have sufficient time for recuperating from work stress and for family life [44,45]. Therefore, employees who have prospects of working in a flexible routine are able to preserve work-life balance, and they reciprocate with stronger commitment towards the organization, and this argument endorses the social exchange theory $[36,46]$. The work-life balance considers the perceived fair treatment and the position it has in the social exchange process [47].

Organizations should put in effort to aid the employees towards integrating their family and work life [48]. A higher level of job satisfaction increases the probability of the employee feeling more attached to the organization, which consequently increases their level of affective organizational commitment [49].

In light of the above literature, the following relationship was hypothesized:

H1a. Work-life balance has a significantly positive relationship with affective organizational commitment.

\subsubsection{Person-Job Fit and Affective Organizational Commitment}

The literature has theoretically explained the relationship of person-job fit and affective organizational commitment with the help of social exchange theory (SET), but empirical testing has largely been scarce $[29,30]$. Person-job fit (PJ fit) is defined as "the match between an individual and the requirements of a specific job" [50]. PJ fit specifically refers to the extent to which the qualifications, skills, knowledge, and abilities of an individual are in line with the requirements of the job [51]. The underlying principle with regards to PJ fit is that employees' personal endeavors and experiences give form to their own version of reality, including cognitions and emotions, which contribute to job satisfaction and eventually affective organizational commitment [25,52]. Organizations strive to recruit and select such individuals, while academicians have demonstrated a relationship between PJ fit and affective organizational commitment [53]. The achievement of a work objective and a successful work behavior establishes faith in the employee and develops a degree of confidence about their acumen, which are the basics of the concept of social cognitive theory $[54,55]$. This confidence is integral in optimizing levels of motivation and, consequently, the perception of PJ fit for the employee. Kristof-Brown et al. (2005) investigated and concluded that PJ fit has a strong relationship with affective organizational commitment and job satisfaction (Figure 1) [53]. The literature confirms that the perception of this fit significantly contributes to individual performance [56]. A meta-analysis conducted by Verquer et al. (2003) confirms that PJ fit has a significant relationship with job satisfaction and, consequently, with affective organizational commitment [57]. 


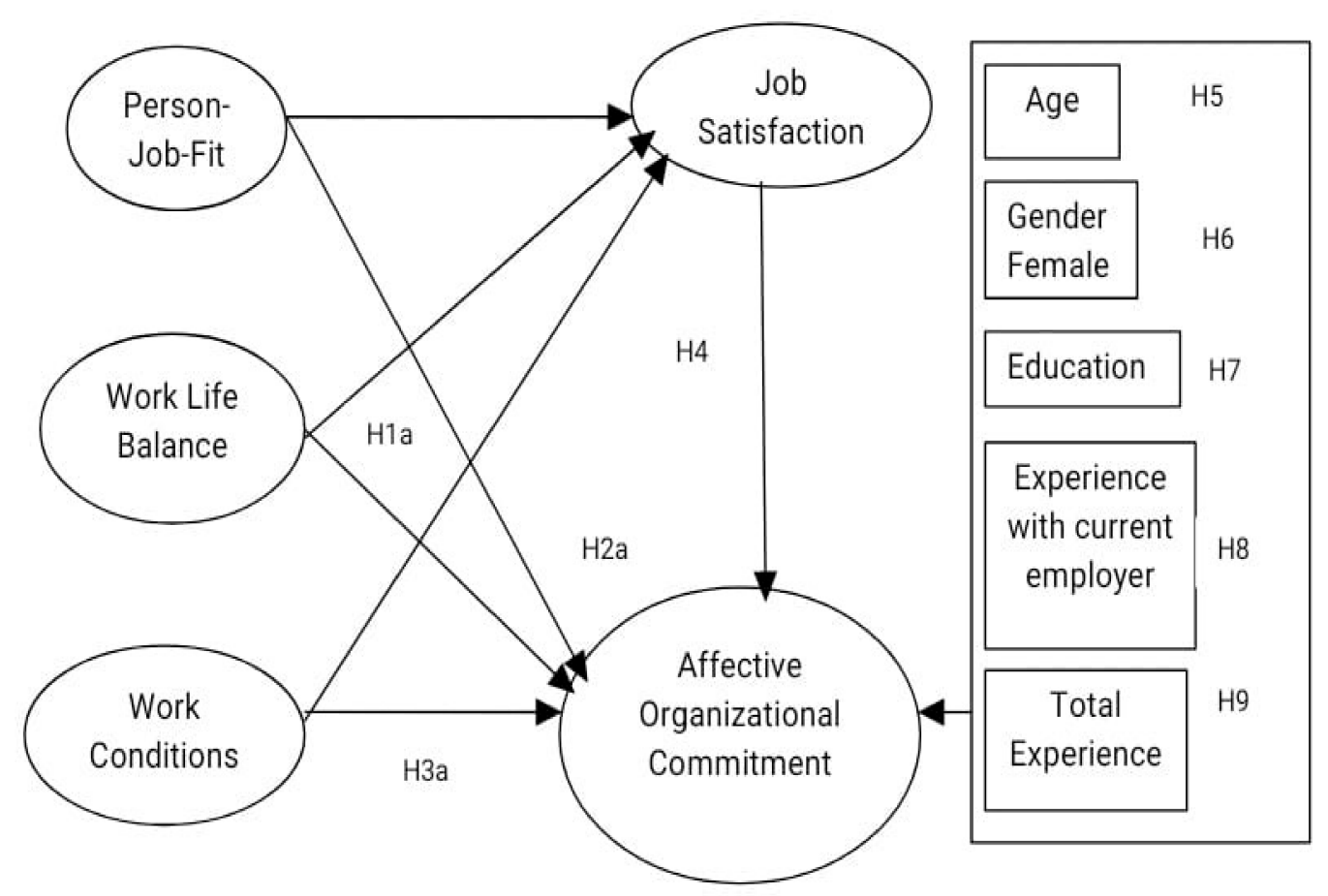

Figure 1. Research Model.

Employees with a higher perceived PJ fit will attach a higher cost to switching organizations, which is the reason that they do not want to potentially miss out on the match between personal abilities and skills with job demands, and eventually the rewards of organizational membership [58]. The opinion about the similarity of personal and organizational values may lead to the perception of increased social demand and importance to conform to organizational values, which leads to amplified affective organizational commitment [59].

In light of the above literature, the following relationship was hypothesized:

H2a. Person-job fit has a significantly positive relationship with affective organizational commitment.

\subsubsection{Work Conditions and Affective Organizational Commitment}

Work conditions have a significant role to play in determining employee engagement, and the literature supports the notion that absenteeism and employee complaints substantially reduce the presence of good work conditions, at the same time decreasing productivity and eventually commitment [60].

Work conditions include the characteristics of the job and workplace structural factors in relation to job satisfaction [61,62]. Significant evidence from the available literature suggests that work conditions influence job satisfaction, as well as the physical and mental well-being of the employee [63,64]. Several studies have revealed that unpleasant work conditions have an effect on the emotional well-being of the employee [65]. Poor work conditions result in employee burnout, and consequently puts emotional stress on them [66]. Conducive work conditions can aid the organization in reducing absenteeism, alleviating grievances at work, elevating job satisfaction, and eventually increasing the affective organizational commitment [67]. Poor work conditions are critical in lowering job satisfaction and performance, while contributing towards a high turnover [63].

Rapid changes and growth in technology require both the development and refinement of skills in the employees, for which the employers strive to provide training and better work conditions, but previous research concludes that such opportunities of skill development and training are not given out equitably [46,68-71]. Alvesson (2000) expressed 
the relevance of work conditions in the light of social exchange theory, and explained that increased commitment is due to the understanding of fairness and mutuality [72]. The employee reciprocates fair treatment and favorable work conditions with increased affective organizational commitment [47].

Private sector companies are continuously striving to maintain greater levels of customer satisfaction, as it is integral to maintain a competitive advantage. Organizations must have good knowledge about maintaining a diverse workforce, which aids in processes from recruitment to the retention of committed employees and guarantee amplified levels of job satisfaction [73].

In light of the above literature, the following relationship was hypothesized:

H3a. Work condition has a significantly positive relationship with affective organizational commitment.

\subsubsection{Job Satisfaction and Affective Organizational Commitment}

Organizations strive to deal with increasing diversity among employees, which requires them to manage the processes of recruitment, challenges of retention, and eventually ensuring high levels of job satisfaction [74]. According to Heathfield (2019), in order to maintain high levels of job satisfaction, it is pertinent to comprehend the elements that lead to it [73]. The influence of human resource management practices on affective organizational commitment has been investigated well in the existing literature, but scarce attention has been given to the psychological aspect that underlies the relationship between these practices and affective organizational commitment [75]. According to social exchange theory, the employers focus on the need fulfillment of the employees, who reciprocate with favorable behavior such as job satisfaction and affective organizational commitment [29]. The exchange between employees and employers is a relationship based on trust and commitment, whereas any discrepancy may end the relationship [76-78]. Therefore, we hypothesized the following:

H4. Job satisfaction has a significantly positive relationship with affective organizational commitment.

Job Satisfaction as a Mediator

The literature shows empirical evidence confirming that when employees feel a similarity between organizational and personal values, they believe they will get better opportunities for skill development from the employer [79]. When employees enjoy a balance in their work and personal life, it leads to greater job satisfaction [29]. When the employee experiences a fit between their skills and the job requirements, then the competence needs are also fulfilled, and consequently, job satisfaction is attained [79]. Furthermore, research by Edwards and Billsberry (2010) explicitly concludes that the gratification of employees' needs greatly influences job satisfaction, which might behave as an intervening variable between the PJ fit and affective organizational commitment relationship $[59,80]$. The connection between human resource management practices and commitment concludes that job satisfaction is a critical precedent of commitment [81]. This connection between satisfaction and commitment is consistent with the idea that amongst the macro notion of affective organizational commitment, satisfaction acts like a microcomponent, and as satisfaction is an employee's attitude towards work, it will be nurtured earlier than commitment [82]. In the service industry, job satisfaction has a deep-rooted effect on the deliverance of customer satisfaction; therefore, satisfied employees lead to satisfied customers [83]. Therefore, we hypothesized the following:

H1b. Job satisfaction mediates the relationship between work-life balance and affective organizational commitment.

H2b. Job satisfaction mediates the relationship between person-job fit and affective organizational commitment.

H3b. Job satisfaction mediates the relationship between work conditions and affective organizational commitment. 


\subsubsection{Affective Organizational Commitment}

The existing literature explains the concept of commitment as a pivotal cognitive process of relating with ones' organization $[84,85]$. Affective organizational commitment of the employee is identified as a psychological attitude that allows the employee to recognize the objectives and ideals of the organization [86]. O'Reilly and Chatman (1986) defined affective organizational commitment as an employee's psychological attachment with the organization, or a bond between employee and the organization $[58,87]$. This bond reduces any chance of "voluntary turnover" [83]. The literature has acknowledged multiple aspects of this psychological bond with the organization [29]. The relationship between the PJ fit, WLB, work conditions, and affective organizational commitment is rooted in social exchange theory [29]. According to Allen and Meyer (1996), affective commitment is represented by the emotional attachment and involvement that an employee feels with the organization [88]. As a result of this, employees experience a sense of motivation to enliven the organization's value system and remain dedicated to the employer [89]. For organizations, employee commitment is of great value, as it leads to a higher job performance, consequently establishing and maintaining a stronger competitive advantage for the company [90].

Employees perceive organizations as an entity that fosters a balance in their work and family life, provides favorable work conditions, and strives to train or develop them to experience a fit between themselves and the organization. As a result, the employee develops a sense of obligation to stay committed to the organization $[48,91]$.

Studies have also identified that affective organizational commitment leads to job satisfaction, while in connection to high-performance work structures; the literature dated to the previous decade suggests a path from affective organizational commitment to job satisfaction [86,92]. In a similar investigation conducted in China, Fu and Deshpande (2014) claimed that a sympathetic atmosphere considerably influenced affective organizational commitment through the intervention of job satisfaction [93]. Another investigation by Fabi et al. (2015) concluded that levels of job satisfaction drastically influence affective commitment, thereby significantly lowering any intention to leave the organization [13]. Although previous studies have shown job satisfaction as both an antecedent [13] and as a consequence of organizational commitment $[81,87,94]$, in the current study, we are investigating job satisfaction as an antecedent of organizational commitment.

According to Lok and Crawford (2004), there is a positive relationship between tenure, educational level, age, and the duration of leadership with affective organizational commitment in East Asian organizations [23]. Mathieu and Zajac (1990), and Chen and Francesco (2000) suggested that variables such as education, age, and leadership duration can have a critical influence on employees' affective organizational commitment $[58,95]$. Another Korean study conducted by Sommer et al. (1996) concluded that age, position, and tenure have a significant relationship with affective organizational commitment amongst Korean respondents [96]. Employees who have spent a long time in a certain organization and have risen to higher levels have greater levels of affective organizational commitment [28]. The studies conducted recently on Western subjects showed consistent results. Sommer et al. (1996) concluded that there was a difference in the relationship between education and affective organizational commitment between earlier findings in Western subjects and Korean subjects, mainly due to contrasting cultures [96]. Looking through the lens of Confucian philosophy, factors such as respect of elders, leadership, education, loyalty, and conformity are diverse between Eastern and Western societies [97-100]. According to Hofstede (2011), women, on average, in most countries, are more likely to choose good work conditions and job security more than men [101]. Comparable differences among gender were also concluded for GLOBE's human orientation measure, which has stressed the social and cultural goals [102]. Based on this literature, it is anticipated that demographic variables, including gender, have a relationship with affective organizational commitment, which should be investigated. 
The current study adds to the existing literature and focuses on emerging economies such as Pakistan in its investigation of the relationships between demographic variables and affective organizational commitment.

H5. Age has a significantly positive relationship with affective organizational commitment.

H6. Female gender has a significantly positive relationship with affective organizational commitment.

H7. Education has a significantly positive relationship with affective organizational commitment.

H8 Experience with a current employer has a significantly positive relationship with affective organizational commitment.

H9. Total experience has a significantly positive relationship with affective organizational commitment.

\section{Materials and Methods}

\subsection{Participants and Procedure}

The researchers sent out a total of 1100 questionnaires, of which 843 responses were received, making the response rate $76.63 \%$. The participants were white-collar (managerial) employees from private sector industries all over Pakistan. Among the participants, $537(63.8 \%)$ were male and $306(36.2 \%)$ were female. Of the participants, $354(42 \%)$ were single and 489 (58\%) were married. As far as education is concerned, $264(31.3 \%)$ had an undergraduate degree from colleges/universities, 489 (58\%) were masters/graduate degree holders, and 90 (10.2\%) held $\mathrm{PhDs} /$ post graduate certifications.

The questionnaire that was filled by the participants consisted of measures of personjob fit, work-life balance, work conditions, job satisfaction, and affective organizational commitment. Data about demographics such as age, gender, education, marital status, total experience in years, and number of years with a current employer were also gathered. For age, the question asked was "What is your current age in years?". For education, the question asked was "How many years of education do you have?". For total experience, the question asked was "How many years of total experience do you have?". For number of years with current employer, the question asked was, "How many years have you been working with the current employer?". These questions were open ended, in which respondents had to write a numerical value and they were all measured as continuous variables.

The participants were assured that a high level of anonymity and confidentiality would be maintained, and that they could withdraw from the study at any time or stage.

\subsection{Common Method Bias}

With regard to PLS-SEM, common method bias might occur because of the use of the same method of measurement as in an SEM study. For example, the responses given by the different respondents might be in the same direction because of the influence of the instructions given at the top of the questionnaire, which might result in the indicators sharing some amount of common variance [103]. Procedural and remedial techniques given by Podsakoff et al. (2003) were applied [104]. With respect to the procedural techniques during data collection, the respondents were instructed not to write their names on the questionnaire, so as to maintain strict anonymity. They were told that there are no correct or incorrect responses, and they must answer in complete honesty. In this way, the respondents' social desirability bias was prevented. Using SPSS, a Harman's single factor test was carried out, which proved that common method variance is not problematic when the total variance explained by one construct is below $50 \%$. An exploratory factor analysis was performed on all of the measurement items using principal components and varimax rotation. The first factor accounted for $36.29 \%$ variance, confirming that there is no threat of common method variance. The remedial technique given by Kock (2015) was also used to see if all inner VIF values were less or equal to 3.3, then the model could be declared to be free of common method bias [103]. The inner values of VIF in the current study met this criterion (Table 1). 
Table 1. Inner VIF values.

\begin{tabular}{cc}
\hline Independent Variables & Affective Organizational Commitment \\
\hline Job satisfaction & 2.756 \\
Person-job fit & 2.342 \\
Working condition & 1.217 \\
Work-life balance & 1.53 \\
\hline
\end{tabular}

\subsection{Measures}

Work-life balance was measured by a 15 item instrument designed to measure worklife balance given by Hayman (2005) [105]. Person-job fit was measured by nine items, called the "global self-report measure of person-job fit", given by Brkich et al. (2002) [106]. Work conditions were measured by five items adapted from The Work Design Questionnaire (WDQ) given by Morgeson and Humphrey (2006) [107]. Job satisfaction was measured by four items taken from an instrument given by Sabri et al. (2011), based on a five-point Likert scale ranging from strongly disagree $=1$ to strongly agree $=5$ [108] . Affective organizational commitment was measured by eight items taken from the Affective Commitment Scale given by Allen and Meyer (1990) [109]. All of these scales were based on a five-point Likert scale ranging from strongly disagree $=1$ to strongly agree $=5$.

\section{Results}

\subsection{Measurement Model}

SmartPLS3 was used to perform the statistical analysis. Reliability was measured through composite reliability (CR) and Cronbach's $\alpha$, as shown in Table 1. The factor loadings above 0.7 were retained and the rest were dropped. Table 1 only lists the items that meet the criterion of factor loading. The values of the average variance extracted (AVE) and composite reliability (CR) are useful in gauging the validity of the scale on our data sample. According to the literature, an acceptable value for AVE is 0.5 or above, and our values met the criterion (Table 2). For each variable, the value of CR should be above 0.7 , and the value of $C R$ for our variables indicated by the results also meets the requirement [110]. The cutoff for Cronbach's $\alpha$ is 0.7 , and the values for all variables were well above the cutoff value.

Confirmatory factor analysis was performed to test the model hypothesized for all five constructs and their respective items. The results of CFA indicated an insignificant difference between the observed and implied models. Standardized root mean square residual (SRMR) was 0.078, and according to Hu and Bentler (1998), a value below 0.08 is generally considered to be an indicator of a good model fit [111]. A value of 0.890 for the Normed Fit Index (NFI) indicated that the projected theoretical model of the study created an adequate fit.

The heterotrait monotrait (HTMT) ratio was the indicator used to measure the discriminant validity, which has a recommended range of below 0.9 [112]. Table 3 shows that the values for the HTMT ratio across all variables were well under 0.9 , which confirmed that the correlation of items across constructs is less than the correlation of items within the same constructs; therefore, the discriminant validity holds. Fornell-Larcker criterion was also used to assess the discriminant validity shown in Table 4. The square root of the AVE of each construct (diagonal in italics) was greater than the correlations between the other constructs. 
Table 2. Measures with scale items, factor loadings, composite reliability, Cronbach's $\alpha$, and average variance extracted (AVE). ${ }^{\circledR}$ reverse coded.

\begin{tabular}{|c|c|c|c|c|c|c|}
\hline Measure/Variable & Item no & Scale/Item & Factor Loading & $\mathrm{CR}$ & Cronbach's $\alpha$ & (AVE) \\
\hline \multirow[t]{5}{*}{ Work-life balance } & WLB1 & $\begin{array}{c}\text { Personal life suffers because of } \\
\text { work. }\end{array}$ & 0.709 & 0.881 & 0.854 & 0.598 \\
\hline & WLB2 & Job makes personal life difficult. & 0.759 & & & \\
\hline & WLB4 & Put personal life on hold for work. & 0.730 & & & \\
\hline & WLB8 & $\begin{array}{l}\text { Personal life drains me of energy } \\
\text { for work. }\end{array}$ & 0.849 & & & \\
\hline & WLB10 & $\begin{array}{l}\text { My work suffers because of my } \\
\text { personal life. }\end{array}$ & 0.811 & & & \\
\hline \multirow[t]{8}{*}{ Person-job fit } & PJF1 & My current job is not really me. ${ }^{\circledR \circledR}$ & 0.864 & 0.950 & 0.939 & 0.703 \\
\hline & PJF2 & $\begin{array}{l}\text { This job is really what I would like } \\
\text { to be doing. }\end{array}$ & 0.890 & & & \\
\hline & PJF3 & $\begin{array}{l}\text { All things considered, this job } \\
\text { suits me. }\end{array}$ & 0.855 & & & \\
\hline & PJF4 & $\begin{array}{l}\text { I feel like this is the right type of } \\
\text { work for me. }\end{array}$ & 0.876 & & & \\
\hline & PJF5 & $\begin{array}{l}\text { I feel that my goals and needs are } \\
\text { met in this job. }\end{array}$ & 0.837 & & & \\
\hline & PJF6 & I find my current job motivating. & 0.854 & & & \\
\hline & PJF7 & $\begin{array}{l}\text { My abilities, skills, and talents are } \\
\text { the right type for this job. }\end{array}$ & 0.776 & & & \\
\hline & PJF9 & $\begin{array}{c}\text { I am able to use my talents, skills } \\
\text { and competencies in my current } \\
\text { job. }\end{array}$ & 0.743 & & & \\
\hline \multirow[t]{5}{*}{$\begin{array}{l}\text { Working } \\
\text { condition }\end{array}$} & WC1 & $\begin{array}{c}\text { The workplace is free from } \\
\text { excessive noise. }\end{array}$ & 0.703 & 0.876 & 0.825 & 0.587 \\
\hline & WC2 & $\begin{array}{l}\text { The climate at the workplace is } \\
\text { comfortable in terms of } \\
\text { temperature and humidity. }\end{array}$ & 0.757 & & & \\
\hline & WC3 & $\begin{array}{c}\text { The job has a low risk of accident. } \\
\text { The job takes place in an }\end{array}$ & 0.704 & & & \\
\hline & WC4 & $\begin{array}{c}\text { environment free from health } \\
\text { hazards (e.g., chemicals, fumes, } \\
\text { etc.) }\end{array}$ & 0.805 & & & \\
\hline & WC5 & $\begin{array}{l}\text { The job occurs in a clean } \\
\text { environment. }\end{array}$ & 0.850 & & & \\
\hline \multirow[t]{7}{*}{$\begin{array}{l}\text { Affective } \\
\text { organizational } \\
\text { commitment }\end{array}$} & OC1 & $\begin{array}{l}\text { I would be very happy to spend } \\
\text { the rest of my career with this } \\
\text { organization. }\end{array}$ & 0.763 & 0.946 & 0.933 & 0.716 \\
\hline & OC3 & $\begin{array}{l}\text { I really feel as if this organization's } \\
\text { problems are my own. }\end{array}$ & 0.746 & & & \\
\hline & OC4 & $\begin{array}{l}\text { I think that I could not easily } \\
\text { become as attached to another } \\
\text { organization as I am to this one. }\end{array}$ & 0.814 & & & \\
\hline & OC5 & $\begin{array}{l}\text { I feel like part of the family at my } \\
\text { organization. }\end{array}$ & 0.872 & & & \\
\hline & OC6 & $\begin{array}{l}\text { I feel emotionally attached to this } \\
\text { organization. }\end{array}$ & 0.888 & & & \\
\hline & OC7 & $\begin{array}{l}\text { This organization has a great deal } \\
\text { of personal meaning for me. }\end{array}$ & 0.909 & & & \\
\hline & OC8 & $\begin{array}{l}\text { I feel a strong sense of belonging } \\
\text { to my organization. }\end{array}$ & 0.912 & & & \\
\hline
\end{tabular}


Table 3. Discriminant validity: Heterotrait Monotrait (HTMT) ratio.

\begin{tabular}{ccccc}
\hline & Job Satisfaction & $\begin{array}{c}\text { Affective } \\
\text { Organizational } \\
\text { Commitment }\end{array}$ & Person-Job Fit & $\begin{array}{c}\text { Working } \\
\text { Condition }\end{array}$ \\
$\begin{array}{c}\text { Work-Life } \\
\text { Balance }\end{array}$ \\
$\begin{array}{c}\text { Job satisfaction } \\
\text { Affective organizational }\end{array}$ & 0.799 & & & \\
commitment & 0.849 & 0.652 & 0.340 & 0.369 \\
Person-job Fit & 0.476 & 0.305 & 0.437 & \\
Working condition & 0.573 & 0.441 & & \\
Work-life balance & & & \\
\hline
\end{tabular}

Table 4. Fornell-Larcker criterion.

\begin{tabular}{ccccc}
\hline & Job Satisfactiaon & $\begin{array}{c}\text { Affective } \\
\text { Organizational } \\
\text { Commitment }\end{array}$ & Person-Job Fit & $\begin{array}{c}\text { Working } \\
\text { Condition }\end{array}$ \\
\hline $\begin{array}{c}\text { Wob satisfaction } \\
\text { Affective }\end{array}$ & 0.808 & & & \\
organizational & 0.717 & 0.846 & & \\
commitment & 0.753 & 0.625 & 0.838 & 0.766 \\
$\begin{array}{c}\text { Person-job Fit } \\
\text { Working condition }\end{array}$ & 0.404 & 0.281 & 0.315 & 0.331 \\
Work-life balance & 0.571 & 0.482 & 0.491 & 0.773 \\
\hline
\end{tabular}

\subsection{Structural Model}

The values of variance inflation factor (VIF) are an indicator of multicollinearity. The results showed (Table 1 ) that all of the values were well below 5 , indicating the absence of multicollinearity, which allowed us to continue to test the mediation model.

\subsubsection{Direct Relationships Latent Variables}

Hypothesis testing was performed using SmartPLS3, as shown in Tables 5-7. Table 5 shows the results of the direct relationships or path analysis of the latent variables. Hypothesis 1a was accepted, which means that work-life balance significantly influences affective organizational commitment. Hypothesis 2 a was also accepted, which confirms that the relationship of person-job fit with affective organizational commitment is also significant. Hypothesis 3a was not accepted, which concludes that work condition is not a significant predictor of affective organizational commitment. Finally, Hypothesis 4 was also accepted, confirming the significant relationship of job satisfaction, which is also the mediator in the study, with affective organizational commitment.

Table 5. SEM path analysis-direct relationships hypothesis testing (latent variables).

\begin{tabular}{cccccc}
\hline Direct Relationships Latent Variables & $\begin{array}{c}\text { Path } \\
\text { Coefficient }\end{array}$ & STDEV & T Statistics & $p$ Values & $\begin{array}{c}\text { Hypothesis } \\
\text { Results }\end{array}$ \\
\hline $\begin{array}{c}\text { Work-life balance } \rightarrow \text { affective } \\
\text { organizational commitment }\end{array}$ & 0.094 & 0.039 & 2.411 & 0.016 & Accepted \\
$\begin{array}{c}\text { Person-job fit } \rightarrow \text { affective organizational } \\
\text { commitment }\end{array}$ & 0.183 & 0.046 & 3.979 & 0.000 & Accepted \\
$\begin{array}{c}\text { Work condition } \rightarrow \text { affective } \\
\text { organizational commitment }\end{array}$ & 0.024 & 0.031 & 0.779 & 0.436 & Not accepted \\
$\quad \begin{array}{l}\text { Job satisfaction } \rightarrow \text { affective } \\
\text { organizational commitment }\end{array}$ & 0.537 & 0.048 & 11.102 & 0.000 & Accepted \\
\hline
\end{tabular}


Table 6. SEM path analysis—direct relationships hypothesis testing (demographic variables).

\begin{tabular}{|c|c|c|c|c|c|}
\hline $\begin{array}{c}\text { Direct Relationships } \\
\text { Demographical Variables }\end{array}$ & $\begin{array}{l}\text { Path } \\
\text { Coefficient }\end{array}$ & STDEV & T Statistics & $p$ Values & $\begin{array}{l}\text { Hypothesis } \\
\text { Results }\end{array}$ \\
\hline $\begin{array}{c}\text { Age } \rightarrow \text { affective organizational } \\
\text { commitment }\end{array}$ & 0.286 & 0.025 & 11.440 & 0.000 & Accepted \\
\hline $\begin{array}{l}\text { Gender female } \rightarrow \text { affective } \\
\text { organizational commitment }\end{array}$ & 0.107 & 0.030 & 3.530 & 0.000 & Accepted \\
\hline $\begin{aligned} \text { Education } \rightarrow & \text { affective organizational } \\
& \text { commitment }\end{aligned}$ & 0.001 & 0.027 & 0.030 & 0.976 & Not accepted \\
\hline $\begin{array}{l}\text { Experience with current employer } \rightarrow \\
\text { affective organizational commitment }\end{array}$ & 0.092 & 0.027 & 3.410 & 0.001 & Accepted \\
\hline $\begin{array}{l}\text { Total experience } \rightarrow \text { affective } \\
\text { organizational commitment }\end{array}$ & 0.062 & 0.030 & 2.103 & 0.036 & Accepted \\
\hline
\end{tabular}

Table 7. SEM mediation path analysis—hypothesis testing (latent variables).

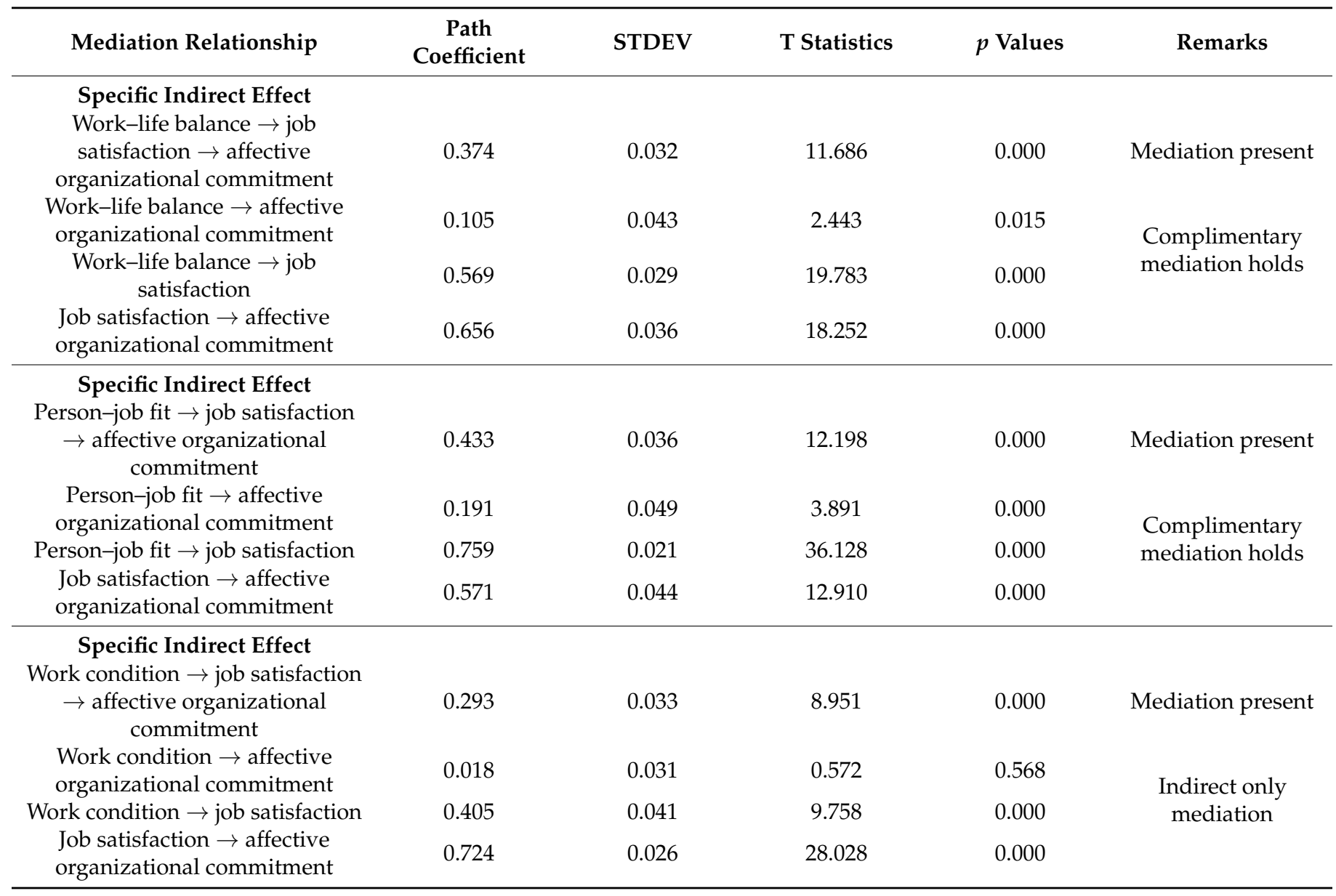

\subsubsection{Direct Relationships Demographic Variables}

Table 6 shows the results of the direct relationships or path analysis of the demographic variables. Hypothesis 5, depicting the relationship of age with affective organizational commitment, was accepted, which means that organizational commitment increases with age. Hypothesis 6, proposing the relationship of female gender with affective organizational commitment, was accepted, concluding that females have a stronger affective organizational commitment compared with males. Hypothesis 7, which is the relationship of education with affective organizational commitment, was insignificant, which means that the number of years of education does not influence the affective organizational commitment of the employee. Hypothesis 8, depicting the relationship of experience with the 
current employer with affective organizational commitment, was accepted, confirming that the more time an employee spends with the current employer, the higher affective organizational commitment there would be. Hypothesis 9 was also accepted, which confirms a significantly positive relationship of total industry experience with affective organizational commitment.

\subsubsection{Mediating Relationships Latent Variables}

Table 7 shows the results regarding the mediation of job satisfaction between worklife balance, person-job fit, work condition, and affective organizational commitment. For Hypothesis $1 b$, the specific indirect effects revealed that job satisfaction mediated the relationship between work-life balance and affective organizational commitment complimentarily. Regarding Hypothesis $2 b$, complimentary mediation of job satisfaction was also found between person-job fit and affective organizational commitment. Although job satisfaction mediated the relationships, which is consistent with our proposed theoretical framework, in the case of work-life balance and person-job fit, the mediation was complementary, which confirms the possibility of an omitted mediator [113]. Complete or full mediation of job satisfaction was found between work condition and affective organizational commitment, resulting in Hypothesis $3 \mathrm{~b}$ being accepted.

\section{Discussion}

Affective organizational commitment and the underlying psychological phenomenon have been of great interest for academicians and practitioners [53,114]. Although the influence of the human resource practices on employee attitudes and behaviors has been under a significant spotlight, the current study, being the first of its kind, adds to the existing literature by unraveling the influence of work-life balance, person-job fit, and work conditions on the affective organizational commitment of employees working in the private sector in an emerging economy such as Pakistan [53].

A distinctive contribution of the current study is the application of social exchange theory (SET) and conservation of resources (COR) theory in order to offer a better understanding concerning the psychological mechanism of these relationships $[30,31]$. Although both SET and COR have been investigated to be central tenets in explaining the employee-organization relationship, the development of these concepts has largely been done separately $[115,116]$. In particular, the investigation of the relationships mentioned above, through the lens of SET and COR, has not yet been the focus in a single study from an emerging economy perspective. Job satisfaction reflects the need for gratification from an SET perspective, while work-life balance and work conditions are strongly linked to COR theory. The current study was structured to incorporate the two theoretical notions in explaining the influence of work-life balance, person-job fit, and work condition on affective organizational commitment, along with the intervening character of job satisfaction.

In line with HR typology presented by Wright and Boswell (2002), the unit of analysis was an individual employee in a South Eastern context, while our sample size was much larger in comparison with Mahmood et al. (2019), Luna-Arocas and Camps (2008), and Fabi et al. (2015) $[1,7,13,117]$. In order to respond to the call of research made by these researchers, this study collected a large sample from private-sector employees in order to provide a greater comprehension of the underlying variables in an emerging economy and South East Asian cultural perspective such as Pakistan. The current study is an attempt to exploit the enlightening influence of said theories, so that a better comprehension and effectiveness of the theoretical model can be presented.

With regards to the hypothesis for direct relationships (latent variables), we see that work-life balance leads to stronger affective organizational commitment. In the private sector, employees seek to work in organizations that provide them with adaptable arrangements at work, so that the employee is able to establish and maintain a balanced work and family life. As a result, the employee reciprocates with augmented affective organizational commitment. These results are consistent with Herrbach et al. (2009) [46]. The results also 
confirm that job satisfaction behaves as a link between work-life balance and affective organizational commitment, but there is a possibility of an omitted variable as the mediation is complimentary. With regards to person-job fit, we find that it leads to amplified affective organizational commitment as well. When a private sector employee realizes that his skill set and aptitude match well with the organization, he values it tremendously and commits himself/herself even more strongly to the organization. Although the mediation is complementary, person-job fit also results in heightened job satisfaction, and consequently raises affective organizational commitment. When it comes to work conditions, we find that it does not influence affective organizational commitment, but the relationship between the two is only established in the presence of job satisfaction. Although work conditions in the private sector might be conducive for facilitating employees, they are not detrimental in the development of strong affective organizational commitment unless an employee is satisfied at the job. Therefore, full mediation is found in this case, and there is no omitted variable in the above-mentioned relationship of work condition. One of the probable reasons that Hypothesis $3 a$ is not supported, is that the validated measures taken from the literature for work conditions might be more relevant to blue color jobs, while the respondents for this research are mainly white collar (managerial) employees who, in a high-power distance society like Pakistan, tend to encounter a better working environment. However, more research is needed to further examine this phenomenon.

One of the interesting findings from the research is the confirmation that stronger affective organizational commitment manifests from higher job satisfaction amongst private sector employees. Thus, for Pakistani private-sector employees, work-life balance and personjob fit significantly influence affective organizational commitment, but work condition increases affective organizational commitment through feelings of job satisfaction alone.

With reference to the influence of demographic variables, we find that as the age of the employee increases, the affective organizational commitment becomes stronger. The relationship of total experience and experience with the current employer is also significant in determining a stronger affective organizational commitment. These findings are consistent with Western culture and also with a study on Korean subjects, but interestingly, Chen and Francesco (2000) had contradictory findings among Chinese subjects $[28,95,96]$. As an employee ages, their experience both in the industry and in the current organization increases; as a result, not only maturity and sensibility sets in, but the understanding of the organizational culture aids in the development of a comfort zone, thereby amplifying affective organizational commitment. The analysis revealed an interesting relationship between gender and education with affective organizational commitment among the sample. In contrast with the results of Western studies, no relationship of education with affective organizational commitment was found in the current study [96]. A possible reason could be that in Pakistan, the education level and the institutional repute are strongly linked with the choice of occupation and organization. This leads to a clearer understanding of the rewards and remuneration. Hence, there are no unmet expectations, resulting in the absence of a significant relationship between the two.

Regarding the relationship of gender with affective organizational commitment, we found that females have a stronger affective organizational commitment than males. Pakistani society is characterized by higher societal concerns for femininity, which is linked with a high commitment by women. The strong affective organizational commitment of women is not due to eccentricity, but due to less tolerance for ambiguity and societal restraint orientation. Because of the underlying patriarchal nature of Pakistani society, women have to face significant hurdles in establishing the freedom needed to carry out a job in the private sector. Once they secure employment, they would most likely show a strong commitment. The findings are consistent with samples from Bulgaria and Romania [118]. Despite the fact that more and more women have entered into the corporate workplaces, these findings also suggest that in Eastern societies, such as Pakistan, the primary responsibility of providing for the family, including elderly parents, wife, and children, is still heavily rested on the male members. Therefore, males are constantly 
striving to seek employment in organizations that offer better remunerations and rewards compared with the current employer. Therefore, males pivot on the skill development, training, and experience gained at the current organization and seek better positions and attached salary enhancement in another organization, which reflects a negative affective organizational commitment with the first.

The results from this study stress the importance of understanding the broad sociohistorical perspective of an emerging economy such as Pakistan. The prevalent high levels of unemployment and poverty coupled with the abundance of labor account for stronger affective organizational commitment. Employees cling to strong unemployment concerns and are cognizant of their substitutability, and therefore, the results are in contrast to affluent nations and developed economies such as Spain, Canada, and those from Central and Eastern Europe [7,13,118].

Human resource practices in private sector organizations are heavily influenced by prevalent cultural values. The current study confirms that cultural and societal norms have a strong influence on the way human resource practices shape the attitudes and levels of commitment amongst private-sector employees. Therefore, other than all endogenous variables of the study, we can say that the decision to leave any organization may be dependent on the economic, cultural, and social variables in private sector organizations in emerging economies such as Pakistan.

\section{Limitations}

Firstly, we used a cross-sectional design, which is not generalizable for longitudinal studies. Longitudinal studies before and after adopting specific HR policies can unearth greater insights into the influence of the independent variables on job satisfaction and affective organizational commitment. Secondly, the current study did not use any qualitative research. We agree with Cooke (2016), who calls for more qualitative research, particularly from less developed and less researched countries, in order to understand the workplace context and offer relevant solutions. In-depth interviews would result in exploring the constructs closely linked to the South Eastern culture that can be more contributive to the research area [119]. Qualitative research could be used to understand the interpretation and relevance of work conditions from an employee's perspective. It could also unearth the most appropriate strategies and policies to achieve work-life balance from a developing country's perspective. Thirdly, the sample was drawn from the entire country, from different private industries, and therefore the influence of a certain sector on the affective organizational commitment could not be captured. The information regarding employees belonging to multinational organizations or local enterprises was also not catered to during the investigation, and therefore, in the future, researchers could unearth interesting phenomena such as managerial philosophy and cultural differences within the private organizations and the commitment of its employees. Fourthly, we did not include any control variables. A number of variables could be included as control or moderating variables by future researchers. For example, cultural context, as Asian cultures are mostly high context compared with Western culture. Additionally, it has been argued that the Hofstede cultural dimension (individualism, power distance, masculinity, and uncertainty avoidance) which influences an individual's cultural values, also influence work-life balance [120]. The size of the firm and the organization's culture could be used as control variables. Lastly, the model is tested in one South Asian country; the replication and testing of this model in other countries may help researchers see its application in other cultural contexts.

\section{Managerial Implications}

Managers are encouraged to improve employee's work life balance by providing assistance at two levels-family and individual. To support individuals, particularly females, who have the dual responsibility of earning the bread and looking after the family in mostly extended family systems in developing countries, managers should offer 
flexible work arrangements, part-time work, parenting resources, lactation support, and child care and eldercare assistance. At an individual level, commuting facility, health and wellness programs, job autonomy, and clarity about their job roles can alleviate work pressures [120]. Traditionally, HRM practices focus on high-performance work practices (HPWP) such as salary, job enrichment, and job stability [7], as well as highperformance work systems (HPWS), for example skill-enhancing, motivation-enhancing, and opportunity-enhancing [13]. Both HPWP and HPWS are relevant once the employee has been hired. However, person-job fit requires managers to spend more time and allocate resources on recruitment and hiring practices. Hiring the right person with the appropriate knowledge and skills for the job necessitates an enhanced and detailed job description, as well as an elaborate recruitment process spanning multiple stages to ensure that candidates' personality, skill set, career aspirations, and motivations match requirements of the job. It is important for recruitment managers to ensure that applicant's personal values match with the organization's culture and norms.

\section{Conclusions}

The current study concludes by establishing the criticality of affective organizational commitment and the anteceding human resource practices in private sector organizations in Pakistan. Private sector organizations seek to have an optimally satisfied and strongly committed workforce. Essentially, the affective organizational commitment becomes stronger when an employee feels congruence between their skill set and the job description. It creates a sense of confidence in them, which results in greater job satisfaction and a stronger organization and commitment. In pursuit of both satisfaction and commitment, HR managers in the private sector need to provide effective training and skill development programs, so that employees undergo a process of self and professional progress, resulting in the establishment of person-job fit. The findings provide support for the COR theory, which suggests that work-life balance is established when an employee gains resources such as energy and time from supervisors [31]. These resources can be channelized into minimizing the tussle between work and family life. In an environment where appraisals are based on performance, employees strive to have high productivity, which can also be achieved if they are able to balance both work and family life. HR managers must actively facilitate an ambience of effective management of professional and family engagements, so that job satisfaction and consequently affective organizational commitment can be influenced [35]. Work conditions were found to be indirectly influencing affective organizational commitment through job satisfaction. When the employer ensures the provisioning of a protective environment; upkeep of the tools, machines, etc.; and safety at the workplace, it is highly likely that the employee will be satisfied at the job and become more committed to the organization. Therefore, it is evident from the study that employees in private sector organizations will feel engaged and experience optimal job satisfaction, resulting in stronger commitment when they practice person-job fit, maintain a balance between work and family life, and have the benefit of favorable work conditions.

Author Contributions: Conceptualization, T.H. and M.J.; methodology, T.H.; software, T.H. and M.J.; validation, T.H. and M.J.; formal analysis, T.H.; investigation, T.H.; resources, T.H.; data curation, T.H.; writing—original draft preparation, T.H.; writing—review and editing, T.H., M.J. and I.B.; visualization, T.H., M.J. and I.B.; supervision, T.H. and I.B. project administration, T.H. and M.J.; funding acquisition, not applicable. All authors have read and agreed to the published version of the manuscript.

Funding: This research received no external funding.

Institutional Review Board Statement: Not applicable.

Informed Consent Statement: Informed consent was obtained from all the respondents involved in the study. All respondents were ensured of anonymity and confidentiality of the responses was maintained. The respondents were informed about the publication of the results. 
Data Availability Statement: The study collected large scale primary data for the current research and probable future studies; therefore, the data cannot be made publicly available.

Acknowledgments: The authors would like to acknowledge the facilitation of Institute of Business Administration, in data collection.

Conflicts of Interest: The authors declare no conflict of interest.

\section{References}

1. Mahmood, A.; Akhtar, M.N.; Talat, U.; Shuai, C.; Hyatt, J.C. Specific HR practices and employee commitment: The mediating role of job satisfaction. Empl. Relat. Int. J. 2019, 41, 420-435. [CrossRef]

2. Lumley, E.J.; Coetzee, M.; Tladinyane, R.; Ferreira, N. Exploring the job satisfaction and organisational commitment of employees in the information technology environment. South. African Bus. Rev. 2011, 15, 100-118.

3. Tariq, A.; Aslam, H.D.; Siddique, A.; Tanveer, A. Work-life balance as a best practice model of human resource management: A win-win situational tool for the employees and organizations. Mediterr. J. Soc. Sci. 2012, 3, 577.

4. Combs, J.G.; Liu, Y.; Hall, A.T.; Ketchen, D. How much do high-performance work practices matter? A meta-analysis of their effects on organizational performance. Pers. Psychol. 2006, 59, 501-528. [CrossRef]

5. Posthuma, R.A.; Campion, M.C.; Masimova, M.; Campion, M.A. A High Performance Work Practices Taxonomy. J. Manag. 2013, 39, 1184-1220. [CrossRef]

6. Huselid, M.A. The impact of human resource management practices on turnover, productivity, and corporate financial performance. Acad. Manag. J. 1995, 38, 635-672. [CrossRef]

7. Luna-Arocas, R.; Camps, J. A model of high performance work practices and turnover intentions. Pers. Rev. 2008, 37, 26-46. [CrossRef]

8. Currall, S.C.; Towler, A.J.; Judge, T.A.; Kohn, L. Pay satisfaction and organizational outcomes. Pers. Psychol. 2005, 58, 613-640. [CrossRef]

9. Beauregard, T.A.; Henry, L.C. Making the link between work-life balance practices and organizational performance. Hum. Resour. Manag. Rev. 2009, 19, 9-22. [CrossRef]

10. Frank, F.D.; Finnegan, R.P.; Taylor, C.R. The race for talent: Retaining and engaging workers in the 21st century. Hum. Resour. Plan. 2004, 27, 12-25.

11. Lavy, V. Using performance-based pay to improve the quality of teachers. Futur. Child. 2007, 17, 87-109. [CrossRef] [PubMed]

12. Warsi, S.; Fatima, N.; Sahibzada, S.A. Study on relationship between organizational commitment and its determinants among private sector employees of Pakistan. Int. Rev. Bus. Res. Pap. 2009, 5, 399-410.

13. Fabi, B.; Lacoursière, R.; Raymond, L. Impact of high-performance work systems on job satisfaction, organizational commitment, and intention to quit in Canadian organizations. Int. J. Manpow. 2015, 36, 772-790. [CrossRef]

14. Rousseau, D.M.; Fried, Y. Location, location, location: Contextualizing organizational research. J. Organ. Behav. 2001, 22, 1-13. [CrossRef]

15. Brewster, C. The HRM/performance link: The effects of geography. Dev. HR Strategy 2007, 14, 5-9. [CrossRef]

16. Lane, C.; Wood, G. Capitalist diversity and diversity within capitalism. Econ. Soc. 2009, 38, 531-551. [CrossRef]

17. Su, Z.X.; Wright, P.M. The effective human resource management system in transitional China: A hybrid of commitment and control practices. Int. J. Hum. Resour. Manag. 2012, 23, 2065-2086. [CrossRef]

18. Jackson, S.E.; Schuler, R.S. Understanding Human Resource Management in the Context of Organizations and their Environments. Annu. Rev. Psychol. 1995, 46, 237-264. [CrossRef] [PubMed]

19. Maharjan, M.; Sekiguchi, T. The influence and effectiveness of US-style and Japanese-style HR practices on Indian firms: A conceptual perspective. South Asian J. Hum. Resour. Manag. 2016, 3, 58-74. [CrossRef]

20. Chen, S.-Y.; Uen, J.F.; Chen, C.-C. Implementing high performance HR practices in Asia: HR practice consistency, employee roles, and performance. Asia Pacific J. Manag. 2016, 33, 937-958. [CrossRef]

21. Chadwick, C.; Super, J.F.; Kwon, K. Resource orchestration in practice: CEO emphasis on SHRM, commitment-based HR systems, and firm performance. Strateg. Manag. J. 2015, 36, 360-376. [CrossRef]

22. Som, A. What drives adoption of innovative SHRM practices in Indian organizations? Int. J. Hum. Resour. Manag. 2007, 18, 808-828. [CrossRef]

23. Paul, A.K.; Anantharaman, R.N. Influence of HRM practices on organizational commitment: A study among software professionals in India. Hum. Resour. Dev. Q. 2004, 15, 77-88. [CrossRef]

24. Azeem, S.M.; Akhtar, N. Job satisfaction and organizational commitment among public sector employees in Saudi Arabia. Int. J. Bus. Soc. Sci. 2014, 4, 127-133.

25. Farzaneh, J.; Dehghanpour, A.; Kazemi, M. The impact of person-job fit and person-organization fit on OCB: The mediating and moderating effects of organizational commitment and psychological empowerment. Pers. Rev. 2014, 43, 672-691. [CrossRef]

26. Akter, A.; Awal Hossen, M.; Islam, M.N. Impact of work life balance on organizational commitment of university teachers: Evidence from Jashore University of Science and Technology. Int. J. Sci. Res. Manag. 2019, 7, 1073-1079. [CrossRef]

27. Jawaad, M.; Amir, A.; Bashir, A.; Hasan, T. Human resource practices and organizational commitment: The mediating role of job satisfaction in emerging economy. Cogent Bus. Manag. 2019, 6, 1608668. [CrossRef] 
28. Lok, P.; Crawford, J. The effect of organisational culture and leadership style on job satisfaction and organisational commitment. J. Manag. Dev. 2004, 23, 321-338. [CrossRef]

29. Straatmann, T.; Königschulte, S.; Hattrup, K.; Hamborg, K.-C. Analysing mediating effects underlying the relationships between P-O fit, P-J fit, and organisational commitment. Int. J. Hum. Resour. Manag. 2020, 31, 1533-1559. [CrossRef]

30. Blau, P.M. Exchange and Power in Social Life, 1st ed.; Wiley: New York, NY, USA, 1964.

31. Hobfoll, S.E. Conservation of resources: A new attempt at conceptualizing stress. Am. Psychol. 1989, 44, 513-524. [CrossRef] [PubMed]

32. Edwards, J.R.; Rothbard, N.P. Mechanisms linking work and family: Clarifying the relationship between work and family constructs. Acad. Manag. Rev. 2000, 25, 178-199. [CrossRef]

33. Lapierre, L.M.; Allen, T.D. Work-supportive family, family-supportive supervision, use of organizational benefits, and problemfocused coping: Implications for work-family conflict and employee well-being. J. Occup. Health Psychol. 2006, 11, 169-181. [CrossRef]

34. Allen, T.D. Family-supportive work environments: The role of organizational perceptions. J. Vocat. Behav. 2001, 58, 414-435. [CrossRef]

35. Odle-Dusseau, H.N.; Britt, T.W.; Greene-Shortridge, T.M. Organizational work-family resources as predictors of job performance and attitudes: The process of work-family conflict and enrichment. J. Occup. Health Psychol. 2012, 17, 28-40. [CrossRef] [PubMed]

36. Tang, S.; Siu, O.; Cheung, F. A study of work-family enrichment among Chinese employees: The mediating role between work support and job satisfaction. Appl. Psychol. 2014, 63, 130-150. [CrossRef]

37. Deery, M. Talent management, work-life balance and retention strategies. Int. J. Contemp. Hosp. Manag. 2008, 20, 792-806. [CrossRef]

38. Doherty, L.; Manfredi, S. Women's progression to senior positions in English universities. Empl. Relat. 2006, $28,553-572$. [CrossRef]

39. Noor, K.M. Work-life balance and intention to leave among academics in Malaysian public higher education institutions. Int. J. Acad. Res. Bus. Soc. Sci. 2011, 2017, 5-19. [CrossRef]

40. Rajadhyaksha, U. Work-life balance in South East Asia: The Indian experience. South Asian J. Glob. Bus. Res. 2012, 1, 108-127. [CrossRef]

41. Greenhaus, J.H.; Collins, K.M.; Shaw, J.D. The relation between work-family balance and quality of life. J. Vocat. Behav. 2003, 63, 510-531. [CrossRef]

42. Dølvik, J.; Waddington, J. Private sector services: Challenges to European trade unions. Transf. Eur. Rev. Labour Res. 2002, 8, 356-376. [CrossRef]

43. Adams, G.A.; King, L.A.; King, D.W. Relationships of job and family involvement, family social support, and work-family conflict with job and life satisfaction. J. Appl. Psychol. 1996, 81, 411-420. [CrossRef]

44. Calasanti, T.M. Gender and life satisfaction in retirement: An assessment of the male model. J. Gerontol. Ser. B 1996, 51B, S18-S29. [CrossRef]

45. Siegrist, J.; Wahrendorf, M.; von dem Knesebeck, O.; Jürges, H.; Börsch-Supan, A. Quality of work, well-being, and intended early retirement of older employees-Baseline results from the SHARE Study. Eur. J. Public Health 2007, 17, 62-68. [CrossRef] [PubMed]

46. Herrbach, O.; Mignonac, K.; Vandenberghe, C.; Negrini, A. Perceived HRM practices, organizational commitment, and voluntary early retirement among late-career managers. Hum. Resour. Manag. 2009, 48, 895-915. [CrossRef]

47. Scholarios, D.; Marks, A. Work-life balance and the software worker. Hum. Resour. Manag. J. 2004, 14, 54-74. [CrossRef]

48. Aryee, S.; Srinivas, E.S.; Tan, H.H. Rhythms of life: Antecedents and outcomes of work-family balance in employed parents. J. Appl. Psychol. 2005, 90, 132-146. [CrossRef] [PubMed]

49. Talukder, A.K.M.M.H. Supervisor support and organizational commitment: The role of work-family conflict, job satisfaction, and work-life balance. J. Employ. Couns. 2019, 56, 98-116. [CrossRef]

50. Lewis, S.; Gambles, R.; Rapoport, R. The constraints of a "work-life balance" approach: An international perspective. Int. J. Hum. Resour. Manag. 2007, 18, 360-373. [CrossRef]

51. O'Reilly, C.A.; Chatman, J.; Caldwell, D.F. People and organizational culture: A profile comparison approach to assessing person-organization fit. Acad. Manag. J. 1991, 34, 487-516. [CrossRef]

52. Sekiguchi, T. How organizations promote person-environment fit: Using the case of japanese firms to illustrate institutional and cultural influences. Asia Pacific J. Manag. 2006, 23, 47-69. [CrossRef]

53. Kristof-Brown, A.L.; Zimmerman, R.D.; Johnson, E.C. Consequences of individuals' fit at work: A meta-analysis of person-job, person-organization, person-group, and person-supervisor fit. Pers. Psychol. 2005, 58, 281-342. [CrossRef]

54. Hannah, S.T.; Schaubroeck, J.M.; Peng, A.C.; Lord, R.G.; Trevino, L.K.; Kozlowski, S.W.J.; Avolio, B.J.; Dimotakis, N.; Doty, J. Joint influences of individual and work unit abusive supervision on ethical intentions and behaviors: A moderated mediation model. J. Appl. Psychol. 2013, 98, 579-592. [CrossRef]

55. Kemp, S.P.; Whittaker, J.K.; Tracy, E.M. Person-Environment Practice: Social Ecology of Interpersonal Helping; Transaction Publishers: Piscataway, NJ, USA, 1997.

56. Lauver, K.J.; Kristof-Brown, A. Distinguishing between employees' perceptions of person-job and person-organization fit. J. Vocat. Behav. 2001, 59, 454-470. [CrossRef] 
57. Verquer, M.L.; Beehr, T.A.; Wagner, S.H. A meta-analysis of relations between person-organization fit and work attitudes. J. Vocat. Behav. 2003, 63, 473-489. [CrossRef]

58. Mathieu, J.E.; Zajac, D.M. A review and meta-analysis of the antecedents, correlates, and consequences of organizational commitment. Psychol. Bull. 1990, 108, 171-194. [CrossRef]

59. Edwards, J.R.; Shipp, A.J. The relationship between person-environment fit and outcomes: An integrative theoretical framework. In Perspectives on Organizational Fit; The Organizational Frontiers Series. Lawrence Erlbaum Associates Publishers: Mahwah, NJ, USA, 2007; pp. 209-258.

60. Roelofsen, P. The impact of office environments on employee performance: The design of the workplace as a strategy for productivity enhancement. J. Facil. Manag. 2002, 1, 247-264. [CrossRef]

61. Campbell, A. Subjective measures of well-being. Am. Psychol. 1976, 31, 117-124. [CrossRef]

62. Kalleberg, A.L.; Griffin, L.J. Positional sources of inequality in job satisfaction. Sociol. Work Occup. 1978, 5, 371-401. [CrossRef]

63. Wells, M.M. Office clutter or meaningful personal displays: The role of office personalization in employee and organizational well-being. J. Environ. Psychol. 2000, 20, 239-255. [CrossRef]

64. Feldman, D.C.; Leana, C.R.; Bolino, M.C. Underemployment and relative deprivation among re-employed executives. J. Occup. Organ. Psychol. 2002, 75, 453-471. [CrossRef]

65. Bashir, A.; Amir, A.; Jawaad, M.; Hasan, T. Work conditions and job performance: An indirect conditional effect of motivation. Cogent Bus. Manag. 2020, 7, 1801961. [CrossRef]

66. Rossberg, J.I.; Friis, S. Patients' and staff's perceptions of the psychiatric ward environment. Psychiatr. Serv. 2004, 55, 798-803. [CrossRef] [PubMed]

67. Gulliver, P.; Towell, D.; Peck, E. Staff morale in the merger of mental health and social care organizations in England. J. Psychiatr. Ment. Health Nurs. 2003, 10, 101-107. [CrossRef] [PubMed]

68. Mustafa, G.; Ali, N. Rewards, autonomous motivation and turnover intention: Results from a non-Western cultural context. Cogent Bus. Manag. 2019, 6, 1676090. [CrossRef]

69. Maurer, T.J.; Rafuse, N.E. Learning, not litigating: Managing employee development and avoiding claims of age discrimination. Acad. Manag. Perspect. 2001, 15, 110-121. [CrossRef]

70. Barth, M.C.; McNaught, W.; Rizzi, P. Corporations and the aging workforce. In Building the Competitive Workforce: Investing in Human Capital for Corporate Success; Mirvis, P.H., Ed.; Wiley: New York, NY, USA, 1993; pp. 156-200.

71. Saba, T.; Guerin, G. Extending employment beyond retirement age: The case of health care managers in Quebec. Public Pers. Manag. 2005, 34, 195-214. [CrossRef]

72. Alvesson, M. Social indentity and the problem of loyalty in knowledge-intensive companies. J. Manag. Stud. 2000, 37, 1101-1124. [CrossRef]

73. Heathfield, S.M. Keys to Employee Satisfaction. Available online: https://www.thebalancecareers.com/keys-to-employeesatisfaction-1918009 (accessed on 16 April 2021).

74. Christensen Hughes, J.; Rog, E. Talent management. Int. J. Contemp. Hosp. Manag. 2008, 20, 743-757. [CrossRef]

75. Kim, M.; Seomun, G. Relationships among burnout, job satisfaction, organizational commitment and turnover intention to resign in hospital nurses. Korean J. Occup. Heal. Nurs. 2013, 22, 93-101. [CrossRef]

76. Cropanzano, R.; Mitchell, M.S. Social exchange theory: An interdisciplinary review. J. Manag. 2005, 31, 874-900. [CrossRef]

77. Saks, A.M. Antecedents and consequences of employee engagement. J. Manag. Psychol. 2006, 21, 600-619. [CrossRef]

78. Foa, E.B.; Foa, U.G. Resource Theory. In Social Exchange: Advances in Theory and Research; Gergen, K., Ed.; Springer: New York, NY, USA, 1980; pp. 77-94.

79. Greguras, G.J.; Diefendorff, J.M. Different fits satisfy different needs: Linking person-environment fit to employee commitment and performance using self-determination theory. J. Appl. Psychol. 2009, 94, 465-477. [CrossRef] [PubMed]

80. Edwards, J.; Billsberry, J. Testing a multidimensional theory of person-environment fit. J. Manag. Issues 2010, 22, 476-493. [CrossRef]

81. Lok, P.; Crawford, J. Antecedents of organizational commitment and the mediating role of job satisfaction. J. Manag. Psychol. 2001, 16, 594-613. [CrossRef]

82. Porter, L.W.; Steers, R.M.; Mowday, R.T.; Boulian, P. V Organizational commitment, job satisfaction, and turnover among psychiatric technicians. J. Appl. Psychol. 1974, 59, 603-609. [CrossRef]

83. Mokaya, S.O.; Musau, J.L.; Wagoki, J.; Karanja, K. Effects of organizational work conditions on employee job satisfaction in the hotel industry in Kenya. Int. J. Arts Commer. 2013, 2, 79-90.

84. Buchanan, B. Building organizational commitment: The socialization of managers in work organizations. Adm. Sci. Q. 1974, 19, 533. [CrossRef]

85. Sheldon, M.E. Investments and involvements as mechanisms producing commitment to the organization. Adm. Sci. Q. 1971, 16, 143-150. [CrossRef]

86. Peng, J.; Li, D.; Zhang, Z.; Tian, Y.; Miao, D.; Xiao, W.; Zhang, J. How can core self-evaluations influence job burnout? The key roles of organizational commitment and job satisfaction. J. Health Psychol. 2014, 21, 50-59. [CrossRef]

87. O'Reilly, C.A.; Chatman, J. Organizational commitment and psychological attachment: The effects of compliance, identification, and internalization on prosocial behavior. J. Appl. Psychol. 1986, 71, 492-499. [CrossRef]

88. Allen, N.J.; Meyer, J.P. Affective, continuance, and normative commitment to the organization: An examination of construct validity. J. Vocat. Behav. 1996, 49, 252-276. [CrossRef] 
89. Meyer, J.P.; Allen, N.J. A three-component conceptualization of organizational commitment. Hum. Resour. Manag. Rev. 1991, 1, 61-89. [CrossRef]

90. Jaramillo, F.; Mulki, J.P.; Marshall, G.W. A meta-analysis of the relationship between organizational commitment and salesperson job performance: 25 years of research. J. Bus. Res. 2005, 58, 705-714. [CrossRef]

91. Rhoades, L.; Eisenberger, R. Perceived organizational support: A review of the literature. J. Appl. Psychol. 2002, 87, 698-714. [CrossRef] [PubMed]

92. Patrick, H.; Sonia, J. Job satisfaction and affective commitment. IUP J. Organ. Behav. 2012, 11, 23-36.

93. Fu, W.; Deshpande, S. The impact of caring climate, job satisfaction, and organizational commitment on job performance of employees in a China's insurance company. J. Bus. Ethics 2014, 124, 339-349. [CrossRef]

94. Dorta-Afonso, D.; González-de-la-Rosa, M.; García-Rodríguez, F.J.; Romero-Domínguez, L. Effects of High-Performance Work Systems (HPWS) on Hospitality Employees' Outcomes Through Their Organizational Commitment, Motivation, and Job Satisfaction. Sustainability 2021, 13, 3226. [CrossRef]

95. Chen, Z.; Francesco, A.M. Employee demography, organizational commitment, and turnover intentions in China: Do cultural differences matter? Hum. Relat. 2000, 53, 869-887. [CrossRef]

96. Sommer, S.M.; Bae, S.-H.; Luthans, F. Organizational commitment across cultures: The impact of antecedents on Korean employees. Hum. Relat. 1996, 49, 977-993. [CrossRef]

97. Cheng, B.S. 'Chaxugeju'(differential mode of association) and Chinese organizational behaviour. Indig. Psychol. Res. Chinese Soc. 1995, 3, 142-219.

98. Knight, J.; Shi, L. Educational attainment and the rural-urban divide in China. Oxf. Bull. Econ. Stat. 1996, 58, 83-117. [CrossRef]

99. El Kahal, S. Business in Asia Pacific: Text and Cases; Oxford University Press: Oxford, UK, 2001.

100. Chen, M. Asian Management Systems: Chinese, Japanese and Korean Styles of Business, 2nd ed.; Cengage Learning: Andover, MA, USA, 2004.

101. Hofstede, G. Dimensionalizing cultures: The Hofstede model in context. Online Readings Psychol. Cult. 2011, 2, 1-26. [CrossRef]

102. House, R.J.; Hanges, P.J.; Javidan, M.; Dorfman, P.W.; Gupta, V. (Eds.) Culture, Leadership, and Organizations: The GLOBE Study of 62 Societies, 1st ed.; SAGE Publications: Thousand Oaks, CA, USA, 2004.

103. Kock, N. Common method bias in PLS-SEM: A full collinearity assessment approach. Int. J. e-Collab. 2015, 11, 1-10. [CrossRef]

104. Podsakoff, P.M.; MacKenzie, S.B.; Lee, J.Y.; Podsakoff, N.P. Common method biases in behavioral research: A critical review of the literature and recommended remedies. J. Appl. Psychol. 2003, 88, 879-903. [CrossRef] [PubMed]

105. Hayman, J. Psychometric assessment of an instrument designed to measure work life balance. Res. Pract. Hum. Resour. Manag. 2005, 13, 85-91.

106. Brkich, M.; Jeffs, D.; Carless, S.A. A global self-report measure of person-job fit. Eur. J. Psychol. Assess. 2002, 18, 43-51. [CrossRef]

107. Morgeson, F.P.; Humphrey, S.E. The Work Design Questionnaire (WDQ): Developing and validating a comprehensive measure for assessing job design and the nature of work. J. Appl. Psychol. 2006, 91, 1321-1339. [CrossRef]

108. Sabri, P.S.U.; Ilyas, M.; Amjad, Z. Organizational culture and its impact on the job satisfaction of the university teachers of Lahore. Int. J. Bus. Soc. Sci. 2011, 2, 121-129.

109. Allen, N.J.; Meyer, J.P. The measurement and antecedents of affective, continuance and normative commitment to the organization. J. Occup. Psychol. 1990, 63, 1-18. [CrossRef]

110. Hair Jr, J.F.; Black, W.C.; Babin, B.J.; Anderson, R.E.; Tatham, R.L. Multivariate Data Analysis, 5th ed.; Prentice Hall: Upper Saddle River, NJ, USA, 1998.

111. Henseler, J.; Ringle, C.M.; Sarstedt, M. A new criterion for assessing discriminant validity in variance-based structural equation modeling. J. Acad. Mark. Sci. 2015, 43, 115-135. [CrossRef]

112. Hu, L.; Bentler, P.M. Fit indices in covariance structure modeling: Sensitivity to underparameterized model misspecification. Psychol. Methods 1998, 3, 424-453. [CrossRef]

113. Zhao, X.; Lynch, J.G., Jr.; Chen, Q. Reconsidering Baron and Kenny: Myths and truths about mediation analysis. J. Consum. Res. 2010, 37, 197-206. [CrossRef]

114. Meyer, J.P.; Stanley, D.J.; Herscovitch, L.; Topolnytsky, L. Affective, continuance, and normative commitment to the organization: A meta-analysis of antecedents, correlates, and consequences. J. Vocat. Behav. 2002, 61, 20-52. [CrossRef]

115. Tavares, S.M.; van Knippenberg, D.; van Dick, R. Organizational identification and "currencies of exchange": Integrating social identity and social exchange perspectives. J. Appl. Soc. Psychol. 2016, 46, 34-45. [CrossRef]

116. Guerrero, S.; Herrbach, O. Manager organizational commitment: A question of support or image? Int. J. Hum. Resour. Manag. 2009, 20, 1536-1553. [CrossRef]

117. Wright, P.M.; Boswell, W.R. Desegregating HRM: A review and synthesis of micro and macro human resource management research. J. Manag. 2002, 28, 247-276. [CrossRef]

118. Peterson, M.F.; Kara, A.; Fanimokun, A.; Smith, P.B. Country culture moderators of the relationship between gender and organizational commitment. Balt. J. Manag. 2019, 14, 389-410. [CrossRef]

119. Cooke, F.L. Concepts, contexts, and mindsets: Putting human resource management research in perspectives. Hum. Resour. Manag. J. 2017, 28, 1-13. [CrossRef]

120. Sirgy, M.J.; Lee, D.J. Work-Life Balance: An Integrative Review. Appl. Res. Qual. Life 2018, 13, 229-254. [CrossRef] 